\title{
The Relationship between Pre-service Teachers' Lifelong Learning Tendencies and Teaching Profession Anxiety Levels
}

\author{
Raşit Özen ${ }^{1, *}$, Duygu Saniye Öztürk² \\ ${ }^{1}$ Department of Educational Sciences, Faculty of Education, Abant Izzet Baysal University, Turkey \\ ${ }^{2}$ Department of Elementary School, Faculty of Education, Abant Izzet Baysal University, Turkey
}

Copyright $\bigcirc 2016$ by authors, all rights reserved. Authors agree that this article remains permanently open access under the terms of the Creative Commons Attribution License 4.0 International License

\begin{abstract}
The present study aims to examine the relationship between pre-service teachers' the lifelong learning tendencies and teaching profession anxiety levels with respect to certain variables (their gender and subject area) and is designed as a survey study. The fourth year pre-service teachers $(n=455)$ in the spring semester of the 2015 - 2016 academic year at Abant Izzet Baysal University, Bolu-Turkey formed the study group. In the study, Lifelong Learning Tendencies Scale by Coşkun [9] and Teacher Candidate Anxiety Scale by Saban, Korkmaz and Akbaşlı [27] were used as data collection instruments. The data were analyzed through using the SSPS for Windows 20 Program and for the analysis of the data, the mean and standard deviation scores were calculated, an independent samples t-test, One-Way ANOVA and LSD tests were used and the Pearson Product-Moment Correlation Coefficient scores were calculated. The findings of the study indicated a significant, positive and low level of relationship between pre-service teachers' lifelong learning tendencies and teaching profession anxiety levels. Significant gender differences were found in favor of male pre-service teachers when lifelong learning tendencies of pre-service teachers are concerned. Also, significant gender differences were found in favor of in favor of female pre-service teachers when their perceptions about their teaching profession anxiety levels are concerned. When pre-service teachers' subject - areas are focus of attention, significant differences were observed in favor of the perceptions of science teaching pre-service teachers when their perceptions about their lifelong learning tendencies and teaching profession anxieties are observed.
\end{abstract}

Keywords Lifelong Education, Teaching Profession Anxiety, Teacher Candidates

\section{Introduction}

In recent years various rapid changes and developments are observed in all areas (science, technology, economy, communication, industry and in other fields of study) in the world. As the consequence of this, people not only have to renew and to update themselves in terms of their knowledge, skills and competencies but also they have to develop themselves both professionally and individually in order to catch up and to keep pace with these changes and developments during their lifespan. In this respect, lifelong learning can be considered as an important concept and European Commission [EC][12] defined lifelong learning as "all learning activity undertaken throughout life, with the aim of improving knowledge, skills and competences within a personal, civic, social and/or employment-related perspective (p:9)". In line with this, lifelong learning describes continuous education opportunities provided for individuals during their lives and supports individuals' learning in accordance with these needs at all ages, in any place and field and which organizes planned activities for this learning [16] and Güleç, Çelik and Demirhan [14] pointed out that lifelong learning can occur wherever people live and eliminates the barriers about the time, people' age and educational level. According to Günüç, Odabaşı and Kuzu [15] formal, informal and learning by experience, age, economy and politics, motivation, teacher as role model, learning by fun, cultural structure, literacy, attitude, competencies, skills, Information and Communication Technologies (ICTs) and experience are the factors associated with lifelong learning.

Meanwhile it is known that the rapid changes and developments in the world effect of people in terms of different aspects and the degree of these effects can show differences among the people as people are different from each other. Therefore; pre-service teachers should be taken into account and investigated during their training periods at the universities in terms of their individual characteristics. In this regard, In this regard, Cabi and Yalçınalp [7] summarize the importance of this is fact as follows: "Prospective teacher's emotions and perceptions are changing so rapidly 
due to recent developments in technology as well as changes in social and economic structures of the societies. In that respect, continuous investigation of students' needs and their characteristics is very important ( $\mathrm{p}: 85$ )."Among these individual characteristics, the affective characteristics of pre-service teachers are considered to be important as they may influence future teachers, their students' behaviors, be related to attrition from teaching profession [20]. One of these affective characteristics is the teaching anxiety of pre-service teachers which is one of many concerns not only of experienced teachers but also something pre-service teachers have to deal with and consider as teaching anxiety has influences upon teachers' classroom behaviours, effectiveness, teaching-learning process and students' achievement levels and their anxiety level ([3]; [25]; [26]). In this regard, Gardner and Leak [13] conceptualized teaching anxiety as anxiety experienced in relation to teaching activities that involve the preparation and execution of classroom activities. Meanwhile, the literature ([4]; [6]; [22]) lists some of the causes of teaching profession anxiety as follows: being appointed as a teacher, Public Personnel Selection Examination (PPSE-KPSS) or finding a job, specific characteristics of learning situations (teaching planning, the ability to analyze problems and learning, classroom management, student assessment), teaching competencies, supervision, professional career and development, being unqualified and skilled in the field of study, the status and the value of the profession in the society, decrease in employment opportunities, working in a different fields, increase in the number of university graduates, heavy work conditions, changing education system.

Concerning the contribution of the present study, it can be stated that changes and developments occurred in all fields in the world changed teachers' roles, responsibilities and duties. This case requires the fact that teachers should have and gain different qualifications from traditional teachers have. In other words, it is believed the teachers should be lifelong learners and have the skills that lifelong learners have. The case that teachers become lifelong learners and have the qualifications and skills that lifelong learners have is closely related to their training periods in the Education Faculties they have undergone in their pre-service period. In consequence, the training period that pre-service undergone in the Education Faculties ensures and requires them to have necessary qualifications teaching profession and the time in which they live requires in order to perform their roles, to take over their responsibilities and to fulfill their duties and tasks which are anticipated from teachers as a result of changes and developments in the world. That is to say, the training period they undergone ensures that pre-service teachers should become lifelong learners and have the necessary skills and competencies that lifelong learners have ([19]; [29]; [36]). Therefore, it can be said that lifelong learning concept implies education programs in general but university education programs in particular [24]. Meanwhile, Titrek, Güneş and Sezen [34] stated that today, universities are affected by the information society and globalization. As the consequence of this, university students are expected to have necessary knowledge and skills required by the information society and the globalization. In other words, the university students are expected to be aware of the necessary lifelong learning knowledge and skills, as: to reach knowledge, to analyze knowledge and to renew and update it for his/her business purposes and to increase his/her knowledge capacity. Furthermore, as the reflections of these changes and developments in all areas, not only in service teachers but also and pre-service teachers think that what they gained during their training period do not meet the demands of the societies and the time in which they live. Consequently, they become anxious about their knowledge, skills and their competencies that they gained in the Faculties of Education in order to solve the problems they encounter in and out of school. As Akgün and Özgür [2] stated as the consequence of the changes and developments in the world, pre-service teachers can feel that they have to improve themselves and what they acquire and learn so far do not meet the requirements of the time in which they live (i.e. they become anxious about their professions). This can lead to have negative attitudes towards their professions, can decrease their self-efficacy beliefs, their self-confidence, their classroom performance, students' academic achievement levels and other negative consequences about their professions, themselves and their students. Therefore, pre-service teachers' lifelong learning tendencies and anxieties about teaching profession should be determined. Within this framework, the aim of the present study is to examine the relationship between the lifelong learning tendencies of pre-service teachers and of their teaching profession anxiety levels with respect to certain variables (their gender and subject area). In line with the aim of the study, the following questions below were answered in the study:

1. What are the lifelong learning tendency levels of pre-service teachers?

2. What are the teaching profession anxiety levels of pre-service teachers?

3. Do pre-service teachers' lifelong learning tendencies significantly relate to their teaching profession anxiety perceptions?

4. Do pre-service teachers' lifelong learning tendencies and teaching profession anxiety perceptions significantly differ as to their gender?

5. Do pre-service teachers' lifelong learning tendencies and teaching profession anxiety perceptions significantly differ as to their subject area?

\section{Method}

\subsection{Research Approach}

This study is a descriptive survey study in order to determine the relationship between the pre-service teachers' perceptions about their lifelong learning tendencies and 
perceptions about their teaching profession anxiety with regard to certain variables (their gender and their subject area) [8]. In this study, the relationship between the pre-service teachers' lifelong learning tendencies and their teaching profession anxiety perceptions are examined with regard to certain variables (their gender, their subject-areas).

\subsection{The Study Group}

In the spring semester of the 2015-2016 academic year, nearly nine hundred pre-service teachers were trained in various majors at Abant Izzet Baysal University, Faculty of Education, Bolu - Turkey. In the present study, even though the surveys were given to 830 pre-service teachers in the spring semester of the 2015-2016 academic year, only 455 pre-service teachers, selected randomly for the study, completed the surveys and 455 surveys were analyzed for the purposes of the present study. Therefore; the study group consisted of $(n=445)$ pre-service teachers who were senior pre-service teachers of Abant Izzet Baysal University, Faculty of Education and who voluntarily participated in the present study On the basis of this, it can be said that the study group $(n=455)$ of the study represented nearly the whole pre-service teachers $(n=900)$ [18] trained in various majors at Abant Izzet Baysal University, Faculty of Education, Bolu - Turkey in the spring semester of the 2015-2016 academic year. When the study group is examined in terms of their gender, it is seen that $74.5 \%(\mathrm{n}=339)$ were female pre-service teachers and $25.5 \%(\mathrm{n}=116)$ were male pre-service teachers. In terms of the subject area the pre-service teachers were studying, they were grouped under four categories by the researchers in the present study, as; Science Teaching (Mathematics Teaching, Science Teaching, Computer and Instructional Technologies Teaching Departments), Social Sciences Teaching (Social Studies Teaching, Special Education Teaching, Classroom Teaching, Preschool Teaching Departments), Fine Arts Teaching (Music and Arts and Crafts Teaching Departments) and Language Teaching (English Language Teaching and Turkish Language Teaching Departments). From the view point of the subject area the pre-service teachers were studying, it is seen that $25.7 \%(\mathrm{n}=117)$ were pre-service teachers of science teaching, $43.3 \%(n=197)$ were pre-service teachers of social sciences teaching, $9.0 \%(\mathrm{n}=41)$ were pre-service teachers of fine arts teaching and $22.0 \%$ $(n=100)$ were the pre-service teachers of language teaching.

\subsection{Data Collection Instruments}

Two data collection instruments, namely; a) Lifelong Learning Tendencies Scale and Teacher Candidate Anxiety Scale were used in the present study.

a) The Lifelong Learning Tendencies Scale (LLTS): The Lifelong Learning Tendencies Scale (LLTS) was prepared and developed by Coşkun [9]. The Lifelong Learning Tendencies Scale is a six-point-Likert type scale ranging from (1) "mostly appropriate" to (6) "never appropriate". There are twenty-seven items on the scale under four sub-scales, namely; Motivation, Persistence, Lack of learning regulation level, and Lack of curiosity (see [9]). In her study Coşkun [9] found a 0.89 Cronbach Alpha reliability score for the whole scale. Where the present study is concerned, the following Cronbach Alpha reliability scores were found: for the whole scale 0.92, for the Motivation sub-scale 0.85, for the Persistence sub-scale 0.87, for the Lack of learning regulation level sub-scale 0.85 , and for the Lack of curiosity sub-scale 0.90 .

b) Teacher Candidate Anxiety Scale (TCAS): Teacher Candidate Anxiety Scale (TCAS) was developed by Saban, Korkmaz and Akbaşlı [27] adopted from Borich by the researchers. The Teacher Candidate Anxiety Scale is a 5-point Likert - type scale ranging from (1) "I am not anxious" to (5) "I am very anxious" [27]. There are 45 items in the scale and the scale has three dimensions namely; Self centered anxiety, Task-centered anxiety and Student-centered anxiety and there are 15 items in each dimension. The highest point in each of these sub-scales is 75 and the point is 15 . In this respect, the highest points indicate high levels of anxiety that a pre-service teacher has. In their study, Saban et al. [27] found the following Cronbach alpha reliability values, as; for self-centered anxiety .76, for task-centered anxiety .73 and .76 for student - centered anxiety dimensions. When the present study is concerned, the following Cronbach alpha reliability values were found, as; for self-centered anxiety .94, for task-centered anxiety. 92 and for student - centered anxiety .96 and for the whole scale .98 the Cronbach alpha reliability value was found.

\subsection{Data Analysis}

The data were analyzed through the SSPS for Windows 20 Program and for the analysis of the data the mean and standard deviation scores were calculated, independent samples t-test, One-Way (ANOVA) and LSD tests were used and the Pearson Product-Moment Correlation Coefficient scores were calculated. Additionally, during the analysis of the data collected through LLTS, the respective scores of the interval scale from one to six converted as follows: " $1=0-26$ (not suitable), $2=27-53$ (partly is not suitable), $3=54-81$ (very slightly not suitable), $4=82-108$ (very slightly suitable), $5=109-135$ (partly suitable), $6=136-162$ (very suitable)" (see [10]). For the analysis of the data collected through TCAS, the respective scores of the interval scale from one to five converted as follows: " $1=0-44$ scores (very low), $2=45-89$ scores (low), $3=90-134$ (moderate), $4=135-179$ (high), $5=180-225$ (very high)".

\section{Findings}

The findings on pre-service teachers' perceptions about their lifelong learning tendencies (LLT) and teaching profession anxieties (TPA) are presented in Tables 1, 2, 3, 4, 5 and 6. 
Table 1. Findings about Pre-service Teachers' Perceptions about Their LLT and TPA Levels

\begin{tabular}{lccccc}
\hline Scales and Sub scales & $\mathrm{N}$ & $\mathrm{Mean}$ & $\mathrm{Sd}$ & Minimum & Maximum \\
\hline Motivation & 455 & 10.81 & 4.032 & 6 & 32 \\
Perseverance & 455 & 14.04 & 5.032 & 6 & 36 \\
Lack of regulating learning & 455 & 14.43 & 7.225 & 6 & 9 \\
Lack of curiosity & 455 & 23.05 & 10.249 & 54 & 134 \\
\hline Lifelong Learning Tendencies Scale (LLTS) & 455 & 62.34 & 20.634 & 28 & 74 \\
\hline Self-centered anxiety & 455 & 34.19 & 11.846 & 15 & 75 \\
Task - centered anxiety & 455 & 36.14 & 11.007 & 15 & 75 \\
Student-centered anxiety & 455 & 35.91 & 13.396 & & 45 \\
\hline Teacher Candidate Anxiety Scale (TCAS) & 455 & 106.24 & 4.552 & & 45 \\
\hline
\end{tabular}

When the findings on pre-service teachers' perceptions regarding their lifelong learning tendencies are examined, it is seen that the mean score for their lifelong learning tendencies was $(\mathrm{M}=62.34, \mathrm{SD}=20.634)$ (see Table 1$)$. In the light of this, it can be said that the pre-service teachers' lifelong learning tendencies are at "moderate level". This finding can mean that to some extent they are aware of the fact that they should develop themselves both professionally and individually and they realize the importance of lifelong learning. Additionally, when teaching profession anxiety levels of pre-service teachers are concerned, it is seen the mean score for their perceptions about their teaching profession anxiety level was $(\mathrm{M}=106.24, \mathrm{SD}=34.552)$. This can mean that their perceptions about their teaching profession anxiety are at "moderate level", as shown in Table 1 . This finding can imply that to a some degree, they know that they will have some difficulties at their schools when they are appointed as a teacher since during the study they were taking Teaching Practice Course.

Table 2. Findings about the Relationship between Pre-service Teachers' LLT and TPA Levels

\begin{tabular}{|c|c|c|c|c|c|c|c|c|c|}
\hline & 1 & 2 & 3 & 4 & 5 & 6 & 7 & 8 & 9 \\
\hline 1.Motivation & 1 & & & & & & & & \\
\hline 2.Perseverance & $.730 * *$ & 1 & & & & & & & \\
\hline 3.Lack of regulating learning & $.258 * *$ & .127 & 1 & & & & & & \\
\hline 4.Lack of curiosity & $.384 * *$ & $.339 * *$ & $.718 * *$ & 1 & & & & & \\
\hline 5.LLTS* & $.654 * *$ & $.599 * *$ & $.788 * *$ & $.906^{* *}$ & 1 & & & & \\
\hline 6.Self - centered anxiety & $.221 * *$ & $.260 * *$ & .090 & .058 & $.167 * *$ & 1 & & & \\
\hline 7.Task - centered anxiety & $.162 * *$ & $.227 * *$ & .014 & -.018 & .083 & $.893 * *$ & 1 & & \\
\hline 8.Student -centered anxiety & $.191 * *$ & .202 & -.003 & -.043 & .064 & $.850 * *$ & $.849 * *$ & 1 & \\
\hline 9.TCAS* & $.202 * *$ & $.240 * *$ & .034 & -.002 & $.108 *$ & $.957 * *$ & $.954 * *$ & $.950 * *$ & 1 \\
\hline
\end{tabular}

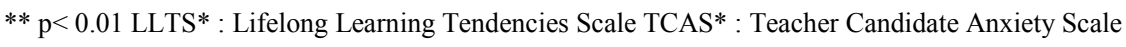

As shown in Table 2, a significant, positive and low level of relationship $(r=0,108, p<.01)$ was found between pre-service teachers' perceptions about their lifelong learning tendencies and teaching profession anxiety levels. On the basis of this finding, it can be said that as the lifelong learning tendency levels of pre-service teachers increase, their teaching profession anxiety levels increase. Additionally, a moderate and low level of relationship was found when the sub - scales of LLTS and TCAS are concerned (see Table 2).

Table 3. Findings about Pre-service Teachers' LLT and Their Gender

\begin{tabular}{|c|c|c|c|c|c|c|c|}
\hline & Gender & $\mathrm{N}$ & Mean & $\mathrm{Sd}$ & $\mathrm{t}$ & $\mathrm{df}$ & $\mathrm{p}$ \\
\hline \multirow[t]{2}{*}{ Motivation } & Female & 339 & 10.4956 & 3.69901 & \multirow{2}{*}{-2.834} & \multirow{2}{*}{453} & \multirow{2}{*}{$.005 *$} \\
\hline & Male & 116 & 11.7155 & 4.78186 & & & \\
\hline \multirow{2}{*}{ Perseverance } & Female & 339 & 13.7994 & 4.81257 & \multirow{2}{*}{-1.792} & \multirow{2}{*}{453} & \multirow{2}{*}{.074} \\
\hline & Male & 116 & 14.7672 & 5.58470 & & & \\
\hline \multirow[t]{2}{*}{ Lack of regulating learning } & Female & 339 & 13.5487 & 6.84441 & \multirow{2}{*}{-4.547} & \multirow{2}{*}{453} & \multirow{2}{*}{$.000 *$} \\
\hline & Male & 116 & 17.0086 & 7.70713 & & & \\
\hline \multirow[t]{2}{*}{ Lack of curiosity } & Female & 339 & 21.8378 & 10.00149 & \multirow{2}{*}{-4.804} & \multirow{2}{*}{453} & \multirow{2}{*}{$.000 *$} \\
\hline & Male & 116 & 26.6034 & 10.18087 & & & \\
\hline \multirow{2}{*}{$\begin{array}{l}\text { Lifelong Learning } \\
\text { Tendencies Scale (LLTS) }\end{array}$} & Female & 339 & 59.6814 & 19.52904 & \multirow{2}{*}{-4.804} & \multirow{2}{*}{453} & \multirow{2}{*}{$.000 *$} \\
\hline & Male & 116 & 70.0948 & 21.87354 & & & \\
\hline
\end{tabular}

\footnotetext{
$*_{\mathrm{p}}<0.05$
} 
When pre-service teachers' lifelong learning tendencies are examined, as in Table 3, a significant difference was observed in favor of male pre-service teachers $(\mathrm{M}=70.0948)[\mathrm{t}(453)=-4.804, \mathrm{p}<0.05]$. This could mean that male pre-service teachers are more open to develop themselves and are more aware of the importance of lifelong learning than female pre-service teachers. Also when the sub-scales of LLTS (Motivation, Perseverance, Lack of regulating learning and Lack of curiosity sub-scales) are concerned, a significant difference was found in favor of male pre-service teachers at $\mathrm{p}=0.05$ level.

Table 4. Findings about Pre-service Teachers' TPA and Their Gender

\begin{tabular}{|c|c|c|c|c|c|c|c|}
\hline & Gender & $\mathrm{N}$ & Mean & $\mathrm{Sd}$ & $\mathrm{t}$ & df & $\mathrm{p}$ \\
\hline \multirow{2}{*}{ Self-centered anxiety } & Female & 339 & 34.6431 & 11.79156 & \multirow{2}{*}{1.406} & \multirow{2}{*}{453} & \multirow{2}{*}{.160} \\
\hline & Male & 116 & 32.8534 & 11.95445 & & & \\
\hline \multirow{2}{*}{ Task - centered anxiety } & Female & 339 & 36.7463 & 10.65602 & \multirow{2}{*}{2.006} & \multirow{2}{*}{453} & \multirow{2}{*}{$.045^{*}$} \\
\hline & Male & 116 & 34.3793 & 11.84733 & & & \\
\hline \multirow{2}{*}{ Student-centered anxiety } & Female & 339 & 36.5811 & 13.52081 & \multirow{2}{*}{1.838} & \multirow{2}{*}{453} & \multirow{2}{*}{.067} \\
\hline & Male & 116 & 33.9397 & 12.88092 & & & \\
\hline \multirow{2}{*}{ Teacher Candidate Anxiety Scale (TCAS) } & Female & 339 & 107.9705 & 34.12853 & \multirow{2}{*}{1.834} & \multirow{2}{*}{453} & \multirow{2}{*}{.067} \\
\hline & Male & 116 & 101.1724 & 35.42543 & & & \\
\hline
\end{tabular}

$* \mathrm{p}<0.05$

Table 5. Findings about Pre-service Teachers' LLT and Their Subject Area

\begin{tabular}{|c|c|c|c|c|c|c|c|}
\hline & & $\begin{array}{l}\text { Sum of } \\
\text { Squares } \\
\end{array}$ & df & $\begin{array}{l}\text { Mean } \\
\text { Square }\end{array}$ & $\mathrm{F}$ & Sig. & $\begin{array}{l}\text { Sources of } \\
\text { differences }\end{array}$ \\
\hline \multirow{3}{*}{ Motivation } & $\begin{array}{l}\text { Between } \\
\text { Groups }\end{array}$ & 10.386 & 3 & 3.462 & \multirow{3}{*}{.212} & \multirow{3}{*}{.888} & \\
\hline & Within Groups & 7372.594 & 451 & 16.347 & & & \\
\hline & Total & 7382.980 & 454 & & & & \\
\hline \multirow{3}{*}{ Perseverance } & $\begin{array}{l}\text { Between } \\
\text { Groups }\end{array}$ & 43.730 & 3 & 14.577 & \multirow{3}{*}{.574} & \multirow{3}{*}{.632} & \\
\hline & Within Groups & 11452.301 & 451 & 25.393 & & & \\
\hline & Total & 11496.031 & 454 & & & & \\
\hline \multirow{3}{*}{ Lack of regulating learning } & $\begin{array}{l}\text { Between } \\
\text { Groups }\end{array}$ & 768.287 & 3 & 256.096 & \multirow{3}{*}{5.037} & \multirow{3}{*}{$.002 *$} & \multirow{3}{*}{$1-3$} \\
\hline & Within Groups & 22931.282 & 451 & 50.845 & & & \\
\hline & Total & 23699.569 & 454 & & & & \\
\hline \multirow{3}{*}{ Lack of curiosity } & $\begin{array}{l}\text { Between } \\
\text { Groups }\end{array}$ & 1652.411 & 3 & 550.804 & \multirow{3}{*}{5.396} & \multirow{3}{*}{$.001^{*}$} & \multirow{3}{*}{$\begin{array}{l}1-2 \\
1-3\end{array}$} \\
\hline & Within Groups & 46040.323 & 451 & 102.085 & & & \\
\hline & Total & 47692.734 & 454 & & & & \\
\hline \multirow{3}{*}{$\begin{array}{l}\text { Lifelong Learning Tendencies Scale } \\
\text { (LLTS) }\end{array}$} & $\begin{array}{l}\text { Between } \\
\text { Groups }\end{array}$ & 4269.648 & 3 & 1423.216 & \multirow{3}{*}{3.396} & \multirow{3}{*}{$.018^{*}$} & \multirow{3}{*}{$\begin{array}{l}1-2 \\
1-3\end{array}$} \\
\hline & Within Groups & 189031.904 & 451 & 419.139 & & & \\
\hline & Total & 193301.552 & 454 & & & & \\
\hline
\end{tabular}

* $p<0.05$ Categories : (1) Science Teaching (2) Social Sciences Teaching (3) Fine Arts Teaching (4) Language Teaching 
When TCAS as a whole is concerned a significant difference was seen in favor of female pre-service teachers where their perceptions about their teaching profession anxieties are focus of attention [ $\mathrm{t}(453)=1.834, \mathrm{p}<0.05$ ] (see Table 4). On the basis of this finding, it can be stated that gender as a variable has an effect on the pre-service teachers' perceptions in relation to their teaching profession anxieties and female pre-service teachers are more anxious about teaching profession than pre-service male teachers. Even though there was a significant difference in favor of female pre-service teachers in the Task - centered anxiety sub- scale of TCAS, there was a significant difference in the Self-centered anxiety and Student-centered anxiety sub-scales of TCAS at $\mathrm{p}=0.05$ level.

Table 5 indicates significant differences among the perceptions of pre-service teachers about their lifelong learning tendencies and their subject- area. When the whole LLTS is concerned, significant differences are observed between the perceptions of science teaching pre-service teachers and of social sciences teaching pre-service teachers and between the perceptions of science teaching pre-service teachers and of fine arts teaching pre-service teachers in favor of the perceptions of science teaching pre-service teachers $[(F(3-451)=3.396, p<0.05)]$ (see Table 5). In their courses, science teaching pre-service teachers deal with real life situations, use problem-based, project-based activities, their courses require experiencing, trying out new things, curiosity, creativity, questioning, inquiry, problem solving, higher order thinking skills for them, social and communication skills, group work activities are important. Therefore, these can be the reasons of the significant differences between the perceptions of science teaching pre-service teachers and of social sciences teaching and fine arts teaching pre-service teachers. Also when the Lack of regulating learning and Lack of curiosity sub- scales of LLTS are concerned, significant differences are observed in favor of the perceptions of science teaching pre-service teachers.

When Table 6 is examined, significant differences are observed among the perceptions of pre-service teachers about their teaching profession anxieties and their subject-area. When the whole TCAS is concerned, significant differences are observed between the perceptions of science teaching pre-service teachers and of social sciences teaching and between the perceptions of science teaching pre-service teachers and of fine arts teaching pre-service teachers in favor of the perceptions of science teaching pre-service teachers $[(\mathrm{F}(3-451)=5.422, \mathrm{p}<0.05)]$ (see Table 6). This can mean that they are more anxious about their teaching profession career than the other departments' pre-service teachers. Also when the Student-centered anxiety sub-scale of TCAS is concerned, significant differences are observed in favor of the perceptions of science teaching pre-service teachers.

Table 6. Findings about Pre-service Teachers' TPA and Their Subject Area

\begin{tabular}{|c|c|c|c|c|c|c|c|c|}
\hline & & & Sum of Squares & $\mathrm{df}$ & Mean Square & $\mathrm{F}$ & Sig. & Sources of differences \\
\hline \multirow{3}{*}{\multicolumn{2}{|c|}{ Self -centered anxiety }} & $\begin{array}{l}\text { Between } \\
\text { Groups }\end{array}$ & 1768.267 & 3 & 589.422 & \multirow{3}{*}{4.292} & \multirow{3}{*}{$.005^{*}$} & \multirow{3}{*}{$\begin{array}{l}2-4 \\
3-4\end{array}$} \\
\hline & & Within Groups & 61938.854 & 451 & 137.337 & & & \\
\hline & & Total & 63707.121 & 454 & & & & \\
\hline \multirow{3}{*}{\multicolumn{2}{|c|}{ Task - centered anxiety }} & $\begin{array}{l}\text { Between } \\
\text { Groups }\end{array}$ & 1648.253 & 3 & 549.418 & \multirow{3}{*}{4.644} & \multirow{3}{*}{$.003 *$} & \multirow{3}{*}{$\begin{array}{c}1-32-4 \\
3-4\end{array}$} \\
\hline & & Within Groups & 53357.461 & 451 & 118.309 & & & \\
\hline & & Total & 55005.714 & 454 & & & & \\
\hline \multirow{3}{*}{\multicolumn{2}{|c|}{ Student -centered anxiety }} & $\begin{array}{l}\text { Between } \\
\text { Groups } \\
\end{array}$ & 3209.828 & 3 & 1069.943 & \multirow{3}{*}{6.166} & \multirow{3}{*}{$.000^{*}$} & \multirow{3}{*}{$\begin{array}{ll}1-2 & 1-3 \\
2-4 & 3-4\end{array}$} \\
\hline & & Within Groups & 78264.295 & 451 & 173.535 & & & \\
\hline & & Total & 81474.123 & 454 & & & & \\
\hline \multirow{3}{*}{$\begin{array}{l}\text { Teacher } \\
\text { Scale(TCAS) }\end{array}$} & \multirow{3}{*}{ Anxiety } & $\begin{array}{l}\text { Between } \\
\text { Groups }\end{array}$ & 18866.144 & 3 & 6288.715 & \multirow{3}{*}{5.422} & \multirow{3}{*}{$.001 *$} & \multirow{3}{*}{$\begin{array}{ll}1-2 & 1-3 \\
2-4 & 3-4\end{array}$} \\
\hline & & Within Groups & 523136.220 & 451 & 1159.947 & & & \\
\hline & & Total & 542002.365 & 454 & & & & \\
\hline
\end{tabular}

* p $<0.05$ Categories : (1) Science Teaching (2) Social Sciences Teaching (3) Fine Arts Teaching (4) Language Teaching 


\section{Results, Conclusions and Recommendations}

The aim of the present study is to examine the relationship between the lifelong learning tendencies of pre-service teachers and of their teaching profession anxiety levels with respect to certain variables (their gender and subject areas). For this purpose, the pre-service teachers $(\mathrm{n}=455)$ answered the data collection instruments, the "Lifelong Learning Tendencies Scale" and the "Teacher Candidate Anxiety Scale " in the spring semester of the 2015-2016 academic year at Abant Izzet Baysal University, Bolu-Turkey. The findings of the present study were limited to the perceptions of AIBU Education Faculty fourth year pre-service teachers $(n=455)$ who participated in the study in the spring semester of the 2015-2016 academic year voluntarily.

When the findings about the pre-service teachers' perceptions about their lifelong learning tendencies $(\mathrm{M}=62.34, \mathrm{SD}=20.634)$ and of their perceptions about their teaching profession anxiety levels $(\mathrm{M}=106.24, \mathrm{SD}=34.552)$ are examined, it is seen that they are at moderate level. When the literature about lifelong learning tendencies of pre-service teachers is reviewed, a similarity is found between the findings of the present study and the literature ([11]; [28]; [31]) as the literature ([11]; [28]; [31]) reported a moderate level lifelong learning tendencies of pre-service teachers when their study groups are concerned.

When the literature about pre-service teachers' teaching profession anxiety levels is examined within the scope of the present study, it is seen that various findings are observed. even though, Akgün and Özgür [2] report a high level teaching profession anxiety levels of pre-service teachers in their study and the literature ([32]; [33]) reports low level of teaching profession anxiety levels of pre-service teachers, the findings of Adigüzelli [1] presents a moderate level teaching profession anxiety levels of pre-service teachers in his study. In this respect, it can be said that there is a similarity between the findings of the present study and the literature.

Where the relationship between the pre-service teachers' lifelong learning tendency and teaching profession anxiety levels is concerned, the findings of the present study, as shown in Table 2, show, a significant, positive and low level of relationship between pre-service teachers' perceptions about their lifelong learning tendencies and teaching profession anxiety levels. Based on this finding, it can be said that as they develop themselves in terms of their knowledge and lifelong learning skills, they realize the difficulties, problems about teaching profession easily and this increases their anxiety levels.

As shown in Table 3 a significant difference in favor of male pre-service teachers is found when their lifelong learning tendencies are examined [ $\mathrm{t}(453)=-4.804, \mathrm{p}<0.05]$. When the literature is examined, it is seen that the literature presents different findings. In this respect, while, Seyhan and Kadı [30] found significant differences in favor of male university students $(\mathrm{Xm}=66.13 ; \mathrm{Xf}=58.59)$ in their study, Beytekin and Kad1 [5] reported that male students have more lifelong learning tendency points than female students $(\mathrm{Xm}=98.38, \mathrm{Xf}=92.52)$. As opposed to the literature above, Oguz and Ataseven [21] and Solmaz and Aydin [31] reported a significant difference between the lifelong learning tendency of female and male students in favor of females. In this regard, Oguz and Ataseven [21] reported a significant difference between the lifelong learning tendency of female $(\mathrm{M}=130.20)$ and male $(\mathrm{M}=125.34)$ students in favor of females $(\mathrm{t}(289)=7.365 ; \mathrm{p}<.05)$. Similarly, Solmaz and Aydin [31] found that the average of female students was found to be higher than that of the male $(\mathrm{M}=124.91$ and $\mathrm{M}=113.46$ respectively) and added that the difference between these points was found to be statistically significant $(\mathrm{t}=3.01 ; \mathrm{p}=0.00)$. Therefore, it can be said that the literature there is a similarity between the findings of the present study and the literature.

Meanwhile, Table 4 indicates a significant difference in favor of female pre-service teachers where their perceptions about their teaching profession anxieties are focus of attention $[\mathrm{t}(453)=1.834, \mathrm{p}<0.05]$ when teacher candidate anxiety scale as a whole is concerned. when the literature is examined, a similar finding is observed between the present study and the literature. In this respect, there is a similarity between the findings of the present study and the findings of Adıgüzelli [1]. In other words, Adıgüzelli[1] pointed out that the pre-service teachers' teaching profession anxiety levels in his study differ significantly according to their gender (Female participants (M=3.21; SD: .92) have more occupational concerns than male participants $(M=3.02$; SD: .95) $[\mathrm{t}(648)=2.77, \mathrm{p}<.05])$.

Table 5 indicates significant differences among the perceptions of pre-service teachers about their lifelong learning tendencies and their subject- area. When the whole LLTS is concerned, significant differences are observed in favor of the perceptions of science teaching pre-service teachers $[(\mathrm{F}(3-451)=3.396, \mathrm{p}<0.05)]$ (see Table 5). When the literature is examined, it is seen that there are different findings concerning the perceptions of pre-service teachers about their lifelong learning tendencies and their subject-area. Even though, the following literature ([21]; [35]) reports significant differences in favor of pre-service science teachers, the following literature ([23]; [36]) reports significant differences in favor of the pre-service teachers of social sciences and fine arts teaching. In this framework, a similarity can be stated between the findings of the present study and the literature.

As seen in Table 6, significant differences are observed among the perceptions of pre-service teachers about their teaching profession anxieties and their subject- area in favor of the perceptions of science teaching pre-service teachers $[(F(3-451)=5.422, p<0.05)]$. As the finding of their study, Karademir and Tezel [17] found that science teaching pre-service teachers have the highest teaching anxiety mean scores. Therefore; it can be said that there is a similarity 
between the findings of the present study and the literature.

In conclusion, it can be said that pre-service teachers believe that they have to develop themselves professionally and individually even though they are equipped with the necessary knowledge, skills and competencies required in their subject- area during their education period at the education faculties, they realize what they learn during their education period is not enough to a certain extent and do not meet the demands of the time in which they live. This can create an anxiety related to their professions to a certain degree.

Based on these, the followings can be recommended:

1. Teacher education programs need to be revised in accordance with the changes and developments in the world in order to increase the lifelong learning tendencies but to reduce the teaching profession anxiety levels of pre-service teachers.

2. Longitudinal studies need to be made in order to examine the changes (if there are any) between lifelong learning tendency and teaching profession anxiety levels of pre-service teachers in a detailed way.

\section{Note}

*The abstract of this paper was presented at 2nd International Conference on Lifelong Learning and Leadership for All (ICLEL-16), in Liepaja on July, 21-23, 2016.

\section{REFERENCES}

[1] Adigüzelli, Y. (2015). Examination of occupational concern of pre-service teachers based on various variables in Turkey. Educational Research and Reviews, 10(4),397-402, DOI: 10.5897/ERR2015.2075. Retrieved at http://www.academicjournals.org/journal/ERR larticle-full-text-pdf/A48E82950485 on January 18,2016.

[2] Akgün, F. and Özgür, H. (2014). Examination of the anxiety levels and attitudes of the information technology pre-service teachers towards the teaching profession. Journal of Theory and Practice in Education, 10(5), 1206-1223.

[3] Akinsola, M.K.(2014). Assessing pre-service teachers teaching anxiety. American Journal of Educational Research,2(12A),41-44,DOI:10.12691/education-2-12A-7.

[4] Atmaca, H.(2013). The professional concerns of teacher candidates who enrolled in English, French and German Teaching Departments. Turkish Studies - International Periodical For the Languages, Literature and History of Turkish or Turkic, 8(10),67-76, DOI : http://dx.doi.Org / 10.7827/TurkishStudies.5907.

[5] Beytekin O.F. and Kad1, A.(2014). Quality of faculty life and lifelong learning tendencies of university students. Higher Education Studies,4(5),28-36.

[6] Bilali, O.and Tarusha, F. (2015). Factors influencing the appearance of teaching anxiety to student teachers. European
Journal of Social Sciences Education and Research, 3(2),90 94.

[7] Cabi, E.and Yalçınalp, S.(2013).Occupational anxiety scale for prospective teachers: A study on validity and reliability. Hacettepe University Journal of Education, 44,85-96.

[8] Christensen L.B., Johnson R.B. and Turner, L.A.(2015). Research methods design and analysis. Ankara: An1 Publishing.

[9] Coşkun, Y.D. (2009). Investigation of lifelong learning tendency of undergraduate students in terms of some variables. Unpublished $\mathrm{PhD}$ Thesis. Ankara: Hacettepe University.

[10] Coşkun, Y.D. and Demirel, M. (2010). Lifelong learning tendency scale: The study of validity and reliability. Procedia-Social and Behavioral Sciences,(5),2343-2350,DOI:10.1016/ j.sbspro.2010.07.461.

[11] Deveci, T. (2015). A comparative study of the lifelong learning propensities of English language learners: Nationality, gender and length of study. Learning \& Teaching in Higher Education: Gulf Perspectives, 12 (1), 1-24, DOI: http://dx.doi.org/10.18538/1the.v12.n1.185. Retrieved at http://the.zu.ac.ae/index.php/lthehome/article/view/185/124 on January 18,2016 .

[12] European Commission (EC).(2001). Making a European Area of Lifelong Learning A Reality. Brussels: European Commission. Retrieved at http://eurlex.europa.eu/LexUriServ/LexUriServ.do?uri=CO M:2001:0678:FIN: EN: PDF on July 27,2015.

[13] Gardner, L. E. and Leak, G. K. (1994). Characteristics and correlates of teaching anxiety among college psychology teachers. Teaching of Psychology,21(1),28-32,DOI:10.1207/ s15328023top2101_5.

[14] Güleç, İ., Çelik, S. and Demirhan, B. (2012). What is lifelong learning? An evaluation on definition and scope. Sakarya University Journal of Education, 2(3),34-48.

[15] Günüç, S.,Odabaş1, H. F. and Kuzu, A. (2012). Factors affecting lifelong learning . University of Gaziantep Journal of Social Sciences, 11(2),309-325.

[16] Güven, M., Yıldırım, E. and Çelen, G.(2015). Metaphors on lifelong learning concept. International Journal of Curriculum and Instructional Studies, 5(9),35-47.

[17] Karademir, E. and Tezel, Ö. (2011). Investigation of preservice teachers' attitude toward teaching profession and anxiety. e-Journal of New World Sciences Academy (NWSA),6(3),2005-2018. Retrieved at http://dergipark .ulakbim .gov.tr/nwsaedu/issue/view/500000 6419 on March 15,2016.

[18] Krejcie, R.V. and Morgan, D.W. (1970). Determining sample size for research activities. Educational and Psychological Measurement,30, 607-610.

[19] Kuzu, S., Demir, S. and Canpolat M. (2015). Evaluation of life-long learning tendencies of pre-service teachers in terms of some variables. Journal of Theory and Practice in Education, 11(4), 1089-1105.

[20] Marso, R.N., and Pigge, F.L. (1998). A longitudinal study of relationships between attitude toward teaching, anxiety about teaching, self-perceived effectiveness, and attrition from teaching.(ERIC Document Reproduction Service No: ED417171). 
[21] Oguz, A. and Ataseven, N.(2016). Relationship between the lifelong learning tendency and information literacy self-efficacy of students. The Anthropologist,24(1), 28-34.

[22] Özen, R. and Ş.S. Nartgün. (2016). Pedagogical formation students \& future. Proceedings Book Vol.1,1 ${ }^{\text {st }}$ International Conference on Lifelong Education and Leadership for All-ICLEL 2015, (pp.411 - 416). Olomouc-Czech, October 29-31.2015.

[23] Ozen, R., Ozturk, D.S. and Ozturk, F.(2016). The relationship between pre-service teachers' lifelong learning tendencies and the quality of university life. The Anthropologist, 24(1), 105-122.

[24] Poyraz, H. and Titrek, O. (2013). Development of lifelong learning in Turkey. Abant Izzet Baysal University Journal of Education Faculty, 13(1),115-131.

[25] Salavera, C. Antoñanzas, J.L., Noé,, R. and Teruel, P. (2014). Emotion and anxiety in teachers: Research of teaching physical education. Procedia - Social and Behavioral Sciences, 132, $577-581$.

[26] Sammephet, B. and Wanphet, P. (2013). Pre-service teachers' anxiety and anxiety management during the first encounter with students in EFL classroom. Journal of Education and Practice, 4(2), 78-87.

[27] Saban, A., Korkmaz, İ. and Akbaşl1, S. (2004). The professional concerns of preservice teachers, Eurasian Journal of Educational Research, (17),198 -209.

[28] Saribas, D.(2015). Investigating the relationship between pre-service teachers' scientific literacy, environmental literacy and life-long learning tendency. Science Education International,26(1),80-100.
[29] Selvi, K. (2011). Teachers' lifelong learning competencies. International Journal of Curriculum and Instructional Studies, 1(1),61-69.

[30] Seyhan, S. and Kadı, A.(2015). Lifelong learning tendencies and media literacy levels of university students. Turkish Social Researches Journal,(3),137-150.

[31] Solmaz, D.Y. and Aydin, G.(2016). Evaluation of lifelong learning tendencies of pre-service teachers. The Anthropologist, 24(1), 55-63.

[32] Tasdemir, C. (2015). Examining occupational anxiety level of mathematics teachers for some variables. Educational Research and Reviews, 10(12), 1578-1585,DOI:10.5897/ERR2015. 2325.

[33] Temiz, E.(2016). Research about occupational anxiety levels of teacher candidates that take pedagogical formation regarding field variable. Global Journal on Humanities \& Social Sciences,(3),180-185, DOI: http://dx. doi.org/10.18844/gjhss.v0i0.297 Retrieved at http://sproc.org/ojs/ index.php/pntsbs/article /view/297 /0 on April 20,2016.

[34] Titrek, O, Güneş, D.Z. and Sezen, G. (2013). Higher Education and Lifelong Learning: A Model Proposal. In: M Elmas (Ed.): International Conference on Quality in Higher Education, ICQH 2013 Proceedings Book, (pp. 1117-1130). Sakarya, Turkey: Sakarya University.

[35] Tunca, N., Alkın Şahin, S. and Aydın, O. (2015). Life-long learning tendencies of pre-service teachers. Mersin University Journal of the Faculty of Education, 11(2),432-446.

[36] Yaman, F. and Yazar, T.(2015). Investigating of lifelong learning tendency of teachers (The example of Diyarbakır). Kastamonu University Kastamonu Education Journal, 23(4),1553-1566. 